\title{
The Concept of Technogenic Social Development
}

\author{
Eduard Semenovich Demidenko ${ }^{1, a}$ \\ ${ }^{1}$ Immanuel Kant Baltic Federal University, 236040, Alexander Nevsky Street 14, Kaliningrad, Russia
}

\begin{abstract}
The article discusses the formation of the modern concept of social development, as opposed to the formational (K. Marx), industrial and postindustrial theories (R. Aron and D. Bell), which do not fully reflect the picture of the society development under the influence of scientific and technical progress. These concepts proceed from the sociological theories, in which the development of a society is based on the social and biospheric nature and is predicated on the natural laws of nature. The society itself, consisting of people, develops on the base of the integration of social, technological and natural processes. It creates the technosphere as a lifeless artificial world with the transition of humanity and biosphere spaces into it. Society, relying on science and machine production, destroys the biosphere and builds a new life, a postbiospheric one. Such a society is not only a technocratic, but also man-caused, as with the loss of soil it will have to produce a biological substance and postbiospheric wild life. The author proves the necessity to move away from technocratic ideas of progress, capitalist development practice by focusing our attention on the socio-economic and political reconstruction of society and the revival of biospheric life, as there are still natural conditions.
\end{abstract}

\section{Introduction}

In the second half of the twentieth century the Marxist social-philosophical concept of changing historical types of socioeconomic formations was rejected by western scientists. In the West, and then in the world there prevailed the industrial and postindustrial theory of social development. R.Dahrendorf and his followers of the theory of industrial society believed that the concept of the capitalist and socialist social systems were only early forms of industrial society [1].

The term "industrial society" of K.A. Saint-Simon received only some updating in the works of O.Cont, K. Marx, E. Durkheim. The concept of the same society was grounded by R. Aron [2] and John Galbraith [3]. It was widespread in the 50-70-ies of the twentieth century in the western sociology. Formation of industrial society was associated with modernization processes on the basis of industrialization and urbanization, with the changes in management, the rationalization of thinking, science, engineering, technology and the entire social system, with the increased role of the nation-state in economy management, democratization and erasing of traditional hereditary differences, increasing social mobility, the availability of education. It should be noted that in this development the ideologues of industrial and urban progress discovered prospects of solving economic, social and domestic problems, improvement of people's well-being, without deep analysis of the consequences of technocracy in the development of the nature biosphere, of the social organism and the urban person.

On the basis of these ideas and changes in societies of developed countries D.Bell's concept of postindustrial society has been based since the 60-ies of the twentieth century [4], which was developed in the general methodological outline, without a description of the particular society. Bell did not protest against refinements of his concept in the process of informatization. In the early $60 \mathrm{~s}$ the term "knowledge society" was introduced by F. Machlup and T. Umesao, who studied the dynamics of the science-consuming industries. But as reasonable the concept was widespread only in the 80 s after the release of Y. Masuda's book in 1983, "Knowledge society as post-industrial" [5]. Understanding of the knowledge society as a promising one gains not only the minds of philosophers, sociologists, economists, but also politicians practically all over the world.

It should be noted that the widespread scientists' error in this conception of social development turned out to be due to a number of methodological weaknesses, particularly related to the lack of understanding of the role and importance of philosophy to understand the world on the basis of multidisciplinary researches at significant research isolation of sciences, which are about 500 . On the one hand, we observe the rapid growth of industrial societies all over the world with the

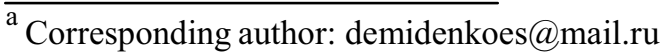


formation of the most developed countries already postindustrial societies (according to D. Bell's theory) after the scientific and technological revolution in the middle of the twentieth century with the growth of the number of workers in the service sector and their decline in the agricultural and industrial production at the expense of innovation development. On the other hand, even in the post-industrial countries we outlook the expansion of the technosphere and growth of artificial life while expanding the service sector. For example, in the US, despite their innovative development of services and production, $95 \%$ of the biosphere forests and soils have degraded and have been destroyed [6], one third of the bees in the world disappeared in 2011 [7], and over the past 10 years over $80 \%$ of the bees disappeared [8], it is noted that one of the highest levels of the human body transformation is beginning of anti-acceleration with unprecedented obesity since childhood, including 28 developed countries [9]. The USA go to an unprecedented rise in the economy and at the same time to the degeneration of biospheric life, including humans, and, with all this going on, D. Bell's theory says about successful development of the post-industrial world.

\section{Results}

Due to the fact that the theory of social development significantly fails in agree with the practice of human and biosphere existence, there is a need for a more careful study of the development of social systems and the theories formation of their historical development. For this purpose the author first applies several new methodological approaches to the analysis of social development and carries out such an analysis in a number of his monographs and articles, as is disclosed in the publication. The author does not reject completely the theoretical studies that have been conducted by many prominent philosophers and scientists, but makes his own substantial adjustments in understanding of society development and the nature of the biosphere as well, including homo sapiens, born by the biosphere and bred by the society. Based on its analysis, the author receives a slightly different picture of the physical world at the present stage, as it will be shown in the course of discussions with philosophers and scientists, still sticking to the positions of formational development, of industrialism and post-industrialism in its various forms, such as the knowledge society. He will also dwell on the issue what should be urgently done for the mankind, for all of us regardless of our social, economic, political and other views and preferences.

\section{Research methods}

Well-chosen methods, both in philosophy and in science, give us the opportunity to explore the most sophisticated and multipurpose objects and their integration development escaping from us. Since development of sociology and the natural sciences, the dialectics of Marxism and Darwin's theory of evolution, there has been accepted and is still carried on a study of social, natural and biological phenomena and processes on the basis of their specific laws independently from one another. In addition, technology and equipment are rapidly evolving in the world, affecting not only the public but also biospheric, natural development. We can say that integrative socio-techno-natural phenomena and processes are evolving in the world, that create integrated patterns of their development. That is what gave the author's article the reason, an engineer by her/his initial education, to take up the study of these phenomena, and then to establish a special scientificphilosophical school of studies of socio-techno-natural processes and social technogenic development of the world in Bryansk State Technical University of the Russian Federation. These studies give rise to the need for a multidisciplinary analysis and deeper research involving methods and theoretical positions of various scientific disciplines, particularly in the area of sociotechno-natural integration. If the practice of interdisciplinary research can ignore philosophy while studying rather a narrow circle of integration of such phenomena, therefore a multidisciplinary approach is unthinkable without social and philosophical generalizations.

Next, D. Bell and his followers do not take into account the following methodological theories like firstly, that society itself develops into a higher-level system - the biosphere - being its subsystem, and secondly, that the biosphere ceases its self-development, that was proved by V.I. Vernadsky, Pierre Teilhard de Chardin, Edouard Le Roy in the twentieth century and it begins to develop humanity, organized in public life.

The most important trend in the field of modern methodology is deep understanding of the fact of life evolution changing on our planet under the influence of development of aggregate human mind, focused on philosophy and sciences. French scientists mentioned above wrote about it along with Vernadsky. "The biosphere has dropped into a new evolutionary state many times ... - wrote V.I.Vernadsky. - This is what we are experiencing now, ... when a person, having developed scientific thought in the social environment, creates a new geological force in the biosphere, which is unprecedented. The biosphere has passed, or better, is moving into a new evolutionary state ... " [10]. This state Edouard Le Roy called "noosphere" but Vernadsky called this concept as concretization of the last state of the biosphere "of the many states of evolution of the biosphere in geological history ..." [11]. The process of tame of biosphere organisms took place by farmers, and Vernadsky hoped for its better continuation under influence of science in the following centuries, up to the tame of chemistry by a person [11].

Based on these important methodological premises, expanding and deepening them, the author has managed to solve some of the theoretical and practical aspects of formation of the concept of technogenic social development and a number of others, which will be discussed below.

\section{Discussion}


During the development of technogenic society, the use of science and developed productive forces for this purpose has led to fundamental changes in the biosphere. Although it is not so simple for evidence of specific conclusions, since the concept of the biosphere itself has several variants, and the author, of course, comes from his understanding of it, including technogenic development of the biosphere with destruction of the life layer, on what neither biologists nor ecologists, nor even philosophers, with few exceptions work. The matter is that philosophers are trying to actively arrange philosophy as an independent and influential science of ideological type, rather than as a basic fundamental teaching, which is based on all the richness of evolutionary development of the world. First of all we are talking about objective information of a great number of sciences about it, not rejecting, of course, important non-scientific knowledge about the world and man, the social experience of mankind, their social and cultural values. Unfortunately, some philosophical worldview systems, divorced from knowledge of real life, can preach "good ideas", leading mankind into the abyss. Such, for example, include the idea of a market economy and competition that have already brought the biosphere to its the death and to which John Galbraith referred as the "innocent fraud" [12].

In our view, the theory of post-industrial and knowledge society cannot claim to be a complete explanation of the modern trends of social, socio-natural and socio-techno-natural development. The concept of post-industrialism corresponds formally in its basis to sociological requirements as it analyses further and wider the changing public body in terms of its complex structure and relationships of people in the course of their life, but at the same time, leaving aside the research results of their impact on the environment.

These comments relate to the methodology of studies of the historical development of the social organism in the relationship with the biosphere, which, unfortunately, is not considered by modern sociologists and social philosophers. The philosophy is called for not only analyzing the general interaction of man and society with the earth, as determined by its very essence as a doctrine, whereof sciences have come out, but also for becoming the head of multidisciplinary research in a fragmentation of the sciences and scientific disciplines (500 and 15 thousand respectively).

Without peculiar properties understanding of the noosphere of human development and mankind in the natural environment and peculiarities of its transition from the natural environment into an artificial one, into the technosphere, we can not understand the current trends in the development of the present society. Thus it is possible to some extent, to refer to the authoritative study of the Austrian mathematician and logician K. Godel, who formulated a theory that gives some clues to the methodology of knowledge socio-techno-natural processes and phenomena. From the theorem it follows: in any sufficiently meaningful theory there are questions that in the framework of this theory cannot be answered it can only be found in a more general theory. From this we can assume: many unresolved questions that remain unanswered in sociology and social philosophy, cause growing criticism of the concept of post-industrialism, unsuccessfully assuming that post-industrialism can be overcome with only expansion of the service sector, not realizing that the service sector is becoming over industrial itself. For example, in the world rather complicated operations have been made no longer by a man, but by a robot. Many people do not understand that the world community (humanity) is a special subsystem of the destroyed BIOSPHERE as a holistic living organism (J. Lovelock) [13], along with the biota, soil and formed by biota unique natural conditions for the development of natural biospheric life. The latter are rapidly destroyed by unorganized activities of people, as mankind lives in market relations and is aimed initially mainly at satisfying personal or family needs at the costs of the biosphere, natural resources, as well as at the expense of vital indestructible - a living material and the soil layer of the biosphere, which must comply with humanitarian principles - live only for revival living. The technogenic society is characterized by highly developed scientific and technological productive forces, the formation of the technosphere (non-living artificial world), which takes both man and socialized living matter of the planet by reducing the biosphere. At the beginning of the twenty first century in the techno sphere there is $40 \%$ by weight of humans and their tamed animals, whereas in 1860 , there was $5 \%$, in 1940 this number was $10 \%$. One-third of the plant world is grown on agricultural soils [14] that in the bulk are man-made with the use of artificial fertilizers and chemicals to increase crop yields, as well as various types of contaminated artificial waste and substantial losses of nutrients. In addition, already $55 \%$ of the land is covered with rootless anthropo-technogenic soils [15]. The technogenic society and its life are formed on the planet.

In turn, this is accompanied by a shrinking of core parts of the biosphere and its ground on the land - soil covering. During the period of 10 thousand years of agriculture development 2 billion ha of land have been destroyed, of which 0.7 billion ha over the last 3 centuries. In operation there are currently 1.5 billion ha [16], which, according to the author's calculations, will be used for the 1.5 century, even if they are being operated with the use of mineral fertilizers and chemical plant protection. The remained undeveloped and poor in humus soil in the area of 1 billion ha will be enough only for 30-40 years for the production of foodstuffs [17]. This will lead to the end of the biospheric life throughout two centuries with the resulting sad consequences for mankind, their life without the biosphere, it is theoretically not excluded. What kind of life it will be, no one knows, if it takes place at all.

As a result, every year not only the basis of the biosphere is shrinking, but also the very biosphere biological substance is reducing. On the planet it is stored in forests, but forests have been reduced by 60 $65 \%$ over a period of productive economy. Where do the living biosphere and biogenetic matter go? As the facts show, they are weathered, washed out from the life layer and eventually discharged into the seas and oceans. These discharges reach enormous sizes. If in the 20 s of 
the twentieth century about 3 billion tons were eventually discharged, in $70 \mathrm{~s}$ years the number of discharges was already about 24 billion tons [18], and now, on the basis of growth dynamics, they are more than 30 billion tons. Biotic cycling of matter is also changing. From the natural cycle it turns into antopogenic-social matter. If in 1800 there was $5.1 \%$ of the townspeople in the world, and in 2015, according to calculations of the author, its number reached $51 \%$, that is, the urban population increased from 45 million to 3.7 billion, or eightyfold. So, from the village more than a half of agricultural products is exported to the city and these products do not come back into soil.

When we consider the overall development of the technogenic society and people in it, then indisputable arguments for its further formation in favor there will be increase in the average life expectancy of the population, social and personal wealth, education and culture, and others. Thus, the average life expectancy of people in the world for two centuries has increased approximately two-fold, up to 67 years [13], the well-being of citizens has grown dozens of times. According to R. Fazorale's data already in the 80 s of the twentieth century such benefits, like a house or apartment, medical services, transportation, communications, education, regular rest and social security, taken together, approximately $40 \%$ of citizens enjoyed them, whereas in the early twentieth century only $1 \%$ could do it [19], including a high level of education, material and spiritual culture, and others.

But at the same time, the growth of welfare of the people is accompanied by the growth of dangerous civilized diseases, particularly cardiovascular diseases, oncology, genetic diseases and others. According to WHO, $90 \%$ of deaths in developed countries accounts for cardiovascular diseases and cancer, whereas in developing countries less than half of deaths is caused by these diseases [20]. If the agricultural societies of the biosphere handicapped children died (in Russia at the end of the nineteenth century $43 \%$ up to 5 years), but now in developed countries, $98 \%$ are able to survive and leave offspring. On average, $7 \%$ of contemporary people have a hereditary genetic burden, whereas in Western Europe it makes more than a fifth of all individuals [20]. The main causes of diseases growth and destruction of the gene pool of humanity is technogenic uncontrolled development of society with the formation of the technosphere and the destruction of the ecological niche of human activity, the transition to the technosphereurban living conditions, pollution, soil exhaustion and people' malnutrition and others.

\section{Conclusion}

As the above brief analysis proves on the globe a system of technogenic societies is actively forming industrial and postindustrial-knowledge ones according to D. Bell. At E.A.Dergacheva's suggestion they can be combined as follows: industrial-technogenic and post-industrialtechnogenic, knowledge-technogenic. They are replacing the biosphere -gathering and agricultural, which developed in the biosphere for about 200 thousand years, with the advent of the Cro-Magnon man. Spontaneous technogenic social development forms the social and technogenic state of the world and life, leading to the rise of the global degradation of the biosphere and even of the human body and their subsequent destruction. The transition of mankind into the postbiosphere world is not excluded, which in contrast to the biosphere does not develop itself, but it is fully determined only by the combined global society. This may complicate human life and the life of biological organisms very much, since the death of the biosphere will change the structure of the atmosphere, and this is bound to demand society to create and maintain a local artificial atmosphere in enclosed technospheric spaces necessary for human life and biota support. Therefore, the most rational human actions are urgent comprehensive studies by the world science of limits in the formation of the technosphere, the destruction of the biosphere and its foundation, soil covering with a further revival of biosphere biological matter and soil covering. This will require the development of programs and the preservation of human biosphere and our natural health.

These and many other proposals for the preservation of biospheric life have been worked out by the author and his students in the most general form [21;22] and need their careful development by the United Nations international teams organized in the framework of the philosophy and science.

\section{References}

1. R. Dahrendorf, Class and class conflict in industrial society (Stanford, 1959)

2. R. Aron, Progress and Disillusion. The Dialectics of Modern Society (N.Y., Washington, L., 1968)

3. J. Galbraith, The new industrial society (Moscow, 1969)

4. D. Bell, The Coming of Post-Industrial Society. A Venture in Social Forecasting (N.Y., 1973)

5. Y. Masuda, The Information Society as PostIndustrial Society (Wash, 1981)

6. G.T. Vorobiev, Scientific and philosophical bases of soil covering (Bryansk, 2014)

7. The disappearance of bees in the world. URL: http://bears.ucoz.ru/news/ischeznovenie_pchel_v_m ire/2011-04-17-362 (2015)

8. The mass death of bees. URL: https://www.forumhouse.ru/threads/93517/ (2015)

9. Modern children have begun antiacceleration. URL: http://g-nina.livejournal.com/627823.html (2016)

10. V.I. Vernadsky, Scientific thought as a planetary phenomenon (Moscow, Nauka, 1991)

11. V.I. Vernadsky, Biosphere. Thoughts and sketches Coll. scientific papers of V.I. Vernadsky (Moscow, Noosphere, 2001)

12. J. Galbraith, Economics of innocent fraud: The truth of our time (Moscow, Europe, 2009)

13. J.E. Lovelock, Gaia: A new look at life on Earth (OxfordUniversity Press, 1979)

14. M.I. Poteev, Concepts of Modern natural science (St. Petersburg, Peter, 1999) 
15. A. Katsura, Z. Otarashvili, The environmental challenge: whether mankind will survive (Moscow, 2005)

16. Global Studies: International Interdisciplinary Encyclopedic Dictionary (Moscow, St. Petersburg, NY, 2006)

17. A.S. Yakovlev, Natural resource bulletin 2 (2014)

18. V.A. Kovda, Questions of sociology (Lions, 1987)

19. R. Fazzorale, The Biosphere Catalogue (London, 1985)

20. V.V. Haskin, T.A. Akimova, T.A. Trifonova, Human ecology (Moscow, 2008)

21. Anthropo-technogenic degradation of the biosphere: overcoming proposals. Works of the Russian Interdisciplinary Scientific and Practical Conference (Moscow, INION RAS, 2014)

22. E.S. Demidenko, E.A. Dergacheva, Technogenic development of society and biosphere transformation (Moscow, Krasand, 2010) 